\title{
THE USE OF TRIADIC SEMANTIC MODEL TO ANALYIZE A DOCUMENTARY MOVIE :LION KINGDOM EPISODE 1: PRIDE AND PUNISHMENT
}

\author{
Zeffi Sugiharto $^{1}$, Widiana Monata ${ }^{2}$, Hendra Husnussalam ${ }^{3}$ \\ ${ }^{1}$ IKIP Siliwangi \\ ${ }^{2}$ IKIP Siliwangi \\ ${ }^{3}$ IKIP Siliwangi \\ ${ }^{1}$ zeff.antisimpatik@gmail.com, ${ }^{2}$ widylagi@ gmail.com, ${ }^{3}$ hendrahusnussalam@ikipsiliwangi.ac.id
}

\begin{abstract}
Charles Sanders Pierce's Triadic semantic model is a semiotic theory that analyze the signs according to the relationship of the represantament and the object. The semantic research on the documentary movie entitled Lion Kingdom, episode 1: Pride and Punishment shows that there are three signs used in the movie. (1) Icon signs, appears 3 times, (2) indexes signs (appears 17 times), and Symbols, appears 15 times.
\end{abstract}

Keywords: Semiotic, Charles Sanders Pierce's, Movie.

\section{INTRODUCTION}

Movie is a form of modern art that uses as media of communication. Oey Hong Lee (2009: 126) in (Pauzan, 2018) defines that a movie is also the second media of communication in the last of $19^{\text {th }}$ century. It means, that just like literature works, a movie consists of signs and messages. Not every messages could be easily recognizable, some messages are embedded in scene and need a method to analyze the message.

A semantic is a study that analyze the message. One of the theory in semantic is theory presented by Charles Sanders Pierce. Through the theory Pierce, define the relationship between the representament and the object, to define the message.

This research is aimed to analyze the scene or fragment of the movie in a documentary movie Lion Kingdom episode 1: Pride and Punishment to analyze the message that wished to achieved by the audience.

Semantic it's a language study about sign and its meaning or message. According to Umberto Eco, semantic is concerned with everything that can be taken as sign (Eco, 1986). the famous theory about semiotics comes from Ferdinand de Saussure, and continued by Roland Barthes. Saussure propose and define a sign into a signifier (significant) and significant (signify), within Saussure's theory, the sign is the results from the association of the signifier with the signified that called signification.

Another expert that discuss about semantics is Charles Sanders Pierce, knows as Triadic model of semantic. According to Umberto Triadic model of semantic consists of:

1. The representament: or sign vehicle

2. An interpretant: not an interpreter but rather the sense made of the sign

3. An object : something beyond the sign to which it refers (referent)(Eco, 1986). According to Peirce (Atkin, 2010), a sign may be termed an icon, an index, or a symbol 
1. Icon is a sign which refers to the object that it denotes merely by virtue of character of its own, and which it procures, just the same, weather any such object actually exist or not.

2. An index is a sign which refers to the object that it denotes by virtue of being reality affected by that object.

3. A symbol, is an assign which refers to the object that it denotes by virtue of a law, usually association of general ideas, which operates to cause the symbol to be interpreted as referring to that object.

There are many linguist who define movie, one of them is Vera (Vera, 2014), she explained that movie in Greek is also known as cinema, cinema is abbreviation of cinematograph (camera brand from Lumiere). In English movie means motion pictures. Another terms that synonyms with movie is film, which according to Joseph V in (Pauzan, 2018), structurally film is formed from many shots, scenes and sequences.

Oey Hong Lee (2009: 126) in Sobur (Sobur, 2003) defines that a movie is also the second media of communication in the last of $19^{\text {th }}$ century. It means, that just like literature works, a movie consists of signs and messages. As the media of communication, movie is divided into some type and genres.

There is two categories of movie movie (Karima \& Maylanny Christin, 2015), namely: fiction and non-fiction. Capwell (Burns, 2009) defines the genres of fiction movie into several categories as follows:

1. Drama,

2. Action movie,

3. Horror movie,

4. Comedy movie,

5. Animation movie, and

6. Science fiction.

In the other hand, non-fiction like a documentary movie, show us of an event like nature, human and animals (Vera, 2014).

\section{METHOD}

This is qualitative research which according to Kaswan and Suprijadi (2016) a qualitative research is synthetic or holistic, heuristic, with little or no control and manipulation of the research. Therefore, this research is aimed to analyze the sign embedded in the movie using Charles Sanders' model. The method used in the research is watch and note.

\section{RESULTS AND DISCUSSION}

\section{Results}

\begin{tabular}{lll}
\hline No & Kinds of signs & $\begin{array}{l}\text { Sign } \\
\text { Description }\end{array}$ \\
\hline 1 & Icon & 3 appearances
\end{tabular}




\begin{tabular}{lll}
\hline 2 & Indexes & 7 appearances \\
\hline 3 & Symbols & 2 appearances
\end{tabular}

Datum 1

\begin{tabular}{ll}
\hline Scene & scene $1(00: 44: 00)$ \\
\hline Context of Situation & $\begin{array}{l}\text { This is the opening scene if the movie. The movie, begin with } \\
\text { an epilogue narrative by the third person narrator that tell } \\
\text { about the plot of the movie. }\end{array}$ \\
\hline "This is a story about three lion pride, battling for control of \\
one forbidden territory. The Glade Pride, small but wise. The \\
Baobab pride, more than thirty strong hunters. The Nza Pride, \\
ferocious power hungry drifter. This is not just a fight for \\
food, it is an all-out war for total dominance. A legacy to gain \\
and everything to lose.
\end{tabular}

Datum 2

\begin{tabular}{lll}
\hline Scene & $:$ & Scene 1 \\
\hline Context of situation & $:$ & $\begin{array}{l}\text { The narrator tell about the setting of the movie that filled by } \\
\text { beautiful animal }\end{array}$ \\
\hline Conversation & $:$ & $\begin{array}{l}\text { It began in the dry season in the bend in the Macuzzi river. Event } \\
\text { in the hottest summer there is always water here, in the place } \\
\text { called the glade }\end{array}$ \\
\hline Kind of signs & $\begin{array}{l}\text { 1. Icon: Elephant and Impala } \\
\text { 2. Indexes: the morning skies, } \\
\text { 3. Symbols, the herd of various animals }\end{array}$
\end{tabular}

\begin{tabular}{ll}
\hline Scene & Scene three \\
\hline Context & $\begin{array}{l}\text { The Nza Pride have a feast on a dead } \\
\text { buffalo as their prey }\end{array}$ \\
\hline Conversation & The Nza pride live on buffalo \\
\hline Kinds of signs & $\begin{array}{l}\text { 1. Icon: the lying lion near others lion } \\
\text { who are eating }\end{array}$ \\
2. Indexes: the fresh bloods on the \\
dead buffalo and the lion pride who \\
are eating the body
\end{tabular}

\begin{tabular}{ll}
\hline Scene & Scene 4 \\
\hline Context & The dying lion, where toture by Nza pride. \\
\hline Narator & They could kill her by now. Instead they torture her. \\
\hline Kinds of sign & indexes: 1. The torturing process
\end{tabular}


3. The lion who is in faint screaming

4. The lions bite the young Baobab Lion

\begin{tabular}{ll}
\hline Scene & Scene 4 \\
\hline Context & $\begin{array}{l}\text { The Baobab Pride come to rescue the young lion who has been } \\
\text { captured by Nza pride }\end{array}$ \\
\hline Narator & $\begin{array}{l}\text { There is only one way to stopped the torture, the Baobab must } \\
\text { submit to Nza }\end{array}$ \\
\hline Kind of signs & Indexes: a pride of lion is approaching an injured lion
\end{tabular}

\begin{tabular}{ll}
\hline Scene & Scene 5 \\
\hline Context & The lion suffered a lot by his \\
& injury. Can't be helped he is \\
& left alone by the pride. \\
\hline Narator & the leader has no choice. \\
& Time for Baobab Pride to \\
& return to his territory. \\
\hline Kinds of sign & Indexes: an injured lion \\
& separated from her pride.
\end{tabular}

\begin{tabular}{ll}
\hline Scene & Scene 5 \\
\hline Context & $\begin{array}{l}\text { The suffering lion is left alone by her pride. Dying in vain, } \\
\text { waiting her death to come. A vulture came closer. }\end{array}$ \\
\hline Narrator & \\
\hline Kinds of sign & Symbols: a vulture bird next to dying lion
\end{tabular}

\begin{tabular}{ll}
\hline Scene & Scene 5 \\
\hline Context & $\begin{array}{l}\text { This is the last moment of the } \\
\text { dying lion. }\end{array}$ \\
\hline Narator & (no words only sad music) \\
\hline Kinds of signs & $\begin{array}{l}\text { Indexes: a colpased lion full } \\
\text { of injury and swamped by } \\
\text { insects }\end{array}$
\end{tabular}

\begin{tabular}{ll}
\hline Scene & Scene 5 \\
\hline Context & $\begin{array}{l}\text { The Glade pride lion, approaching the dead lion. They take a } \\
\text { look on the body and sat near for a moment }\end{array}$ \\
\hline Narator & $\begin{array}{l}\text { The Glade pride is returns with their cubs. Her body all is left } \\
\text { to shows what happen here. There is lessons here. }\end{array}$ \\
\hline Kinds of signs & Indexes: a lion kissing dead
\end{tabular}

\section{Discussion}

\section{Datum 1}


The title Pride and Punishment is stands for the representament, of the object: the lion who is her eyes shut and swarmed by insects. This image represent that lion, the king of the jungle, full pride animal who has been fallen, and faced his death. The word pride in the title represent two ideas: first is to represent a group of lion. In this movie represent to Baobab pride, in which the lion who is arrogant (over pride) came from this herd. The seconds, represent an adjective, synonym of arrogant. This title represent the Full pride Lion who had been punished by nature and meets her ends and been symbolized by the images. The humanism value of the scene is that, as human being, we should keep humble.

\section{Datum 2}

The scene shows us the beautiful scenery of African territory, the Ruaha River. It filed by epidemic and beautiful African animals. The morning scenes represent the early day, a new day to begin. The elephant and antelope indicates the epidemic animals of African. The strong one and beautiful one, all living hormonally in Ruaha River.

\section{Datum 3}

The scene in datum 3 shows the great power of the lion pride. They could hunt a strong and mighty buffalo together. A lying lion in the front with mouth wide open, shows that the lion's belly is already full. While the other lion in the back is still enjoying their feast. This scene represents the messages together we are united, together we strong. It's not just the strength that made the lion became the king of the jungle, but also their togetherness, their willingness to be together in every hunt. And share the prey equally among the pride.

\section{Datum 4}

The scene of datum 4, is the main story of the movie, the climax. This movie is tell about an arrogant lion who has her punishment: a torture. It represents that every act has its own consequences.

\section{Datum 5 and datum 6}

A vulture, is the symbols of death. Whenever it comes, there must be a death nearby. In this scenes vulture represents to a death. On the datum 6, after the venture came, the lion where lying down on the ground. Her injuries are severe and unbearable that made her die.

\section{Datum 7}

The Glade Pride, the wise pride. Has come back again to the territory. They took their cubs to come to watch over the dead body. And the narrators represents the scenes by saying "there is a lesson here" indicates that the cubs try to learn something from this dead lion; 'a punishment'.

\section{CONCLUSION}

The Lion Kingdom is the documentary movie that tells about the life of three lion's pride in the Ruaha. Tough it was the story of animal, however there are many symbols that represents human's life. According to Pierce's Triadic model of sematic, researcher find there are 3 scenes embedded with signs of icon, sign of indexes 15 appearances, and the last signs of icon 10 appearances. Indexes icons become the most sign appear in the movie, it shows the action of 
what is being happening. Trough the using of the symbols, this movie give the audience message.

\section{ACKNOWLEDGMENTS}

Alhamdulillah. We would gladly say thanks to Allah swt, for his mercy and blessing upon the arrangement of this research. Second Shalawat and salaam may always be poured to the Prophet Muhammad, his family and his relative. To our family, and our lecturer who always support us and guide us in this research. Thank you.

\section{REFERENCES}

Atkin, A. (2010). Peirce's Theory Of Signs. Retrieved From Https://Plato.Stanford.Edu/Entries/Peirce-Semiotics/\#Tenclasig

Burns, A. C. (2009). Action, Romance, Or Science Fiction : Your Favorite Movie Genre May Affect Your Communication. 11(4).

Eco, U. (1986). Semiotics And The Philosophy Of Language. Indiana University Press.

Karima, S., \& Maylanny Christin. (2015). Charles Sanders Peirce Semiotic Analysis On The Presentation Of Viocartoons Little Krishna Serial Episode 5 September 2014. 2(2), 22372243.

Kaswan. Dasep Suprijadi. (2016). No Title. Bandung: Putra Praktisi Bandung.

Pauzan, A. A. (2018). A Semiotic Analysis Of The John Wick 1 Film Using Charles Sanders Peirce 'S Semiotic Theory A Thesis.

Sobur, A. (2003). Semiotika Komunikasi. Remaja Rosdakarya.

Vera, N. (2014). Semiotika Dalam Riset Komunikasi. Bogor: Ghalia Indonesia. 